ORIGINAL ARTICLE

AFRICAN JOURNAL OF CLINICAL AND EXPERIMENTAL MICROBIOLOGY AJCEM/201084/21121

COPYRIGHT 2011

AFR. J. CLN. EXPER. MICROBIOL 12(3): 101-105

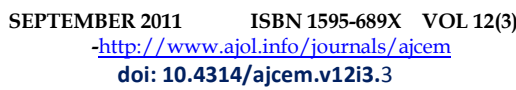

\title{
EXPERIENCE WITH HEPATITIS B VIRAL LOAD TESTING IN NIGERIA
}

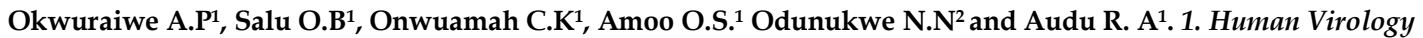 \\ Laboratory, Nigerian Institute of Medical Research, Yaba, Lagos, Nigeria. 2. Clinical Sciences Division, Nigerian \\ Institute of Medical Research, Yaba, Lagos, Nigeria.
}

\begin{abstract}
Background: Quantification of the viral burden is an important laboratory tool in the management of hepatitis B virus (HBV)-infected patients. However, widespread use of assays is still hampered by the high cost. Treatment reduces viral load to undetectable levels. HBV infected patients tend to have high HBV DNA levels, and severe liver disease. Objectives: This study was carried out to determine the pattern of HBV viral load levels of patients assessing management in Nigeria.

Method: Variables included sociodemographics like age, sex, religion, income, educational background and residence. The COBAS Amplicor automated Analyzer (PCR based) was used to assay the virus quantitatively.

Results: 594 patients were tested from 2008 to 2009. Statistical analysis was done using Epi info version 2002 and test of significance by Kruskal-Wallis. Mean age of the patients was 36.8 (ranging from 9 to 69) years. HBV viral titre ranged between 4,145 and 68,011,800 DNA copies $/ \mathrm{ml}$.

Conclusion: There was a high occurrence of viral titre in the population studied. High viral load is a risk factor for hepatocellular carcinoma. A policy earmarked to combat this virus in Nigeria is hereby solicited.
\end{abstract}

Key words: HBV infection, HBV DNA, Nigeria

\section{INTRODUCTION}

Viral hepatitis is as old as the history of medicine. About a third of the world's population, more than 2 billion people, have been infected with the hepatitis B virus [1]. Hepatitis B virus (HBV) infection is a public health problem with 350 million chronic carriers worldwide. An estimated 500,000 to 1.2 million people die of HBV infection annually. The global disease burden is substantial due to its high related morbidity and mortality.

Prevalence varies greatly in different parts of the world, but is higher in tropical regions causing both acute and chronic liver disease [2]. In Nigeria, $11.6 \%$ prevalence rate has been reported from Maiduguri [3], 13.8\% from Lagos [4], 4.3\%

from Port Harcourt [5], 5.7\% from Ilorin [6], 8.3\% from Zaria [7], 17.1\% from female sex workers, $14.9 \%{ }^{[8]}$ from healthy blood donors ${ }^{[9]}$ and $25.7 \%$ among surgeons [10]. Although HBV prevalence varies widely across the African continent, hepatitis B surface antigen (HBsAg) positivity is estimated at $8-20 \%$ [11]. About $15-40 \%$ of $\mathrm{HBV}$ infected patients would develop cirrhosis, liver failure, or hepatocellular carcinoma (HCC) ${ }^{[12] .}$ Jatau et al while working on pregnant women showed that HBV infection increases with age to a level and decreases with higher age [13]. People with chronic hepatitis $B$ virus infection who experience hepatitis B "e" antigen (HBeAg) seroconversion before age 30 have better long- term outcomes - including lower rates of cirrhosis and liver cancer - than those who seroconvert 10 years later [14]. The risk of primary liver cancer increases with age and alcohol consumption [15]. Influence of age on development of $\mathrm{HBV}$ carrier state has been studied and a consistent relation was found.

A study by Chen et al showed a persistent suppression of HBV DNA is important to prevent the development of HCC in known cirrhosis patients [16]. Treatment with the interferon group reduces viral load to undetectable levels with a $50-70 \%$ success rate. $\mathrm{HBV}$ is classified into 8 genotypes, A-H.

In Nigeria, centres where one can assess his or her hepatitis status are many, but for quantitative determinations, they are rare and expensive. Samples have previously been taken outside the country to foreign laboratories. This costly enterprise keeps the test out of reach of the average citizen. However, the HBV DNA test is essential to hepatitis $B$ management.

The purpose of this study was to present the pattern of HBV viral load levels of people in terms of age/sex distribution and zonal distribution in Nigeria.

\section{MATERIALS AND METHODS}

Data, sample collection and processing: A biodata was raised for each of the 594 subjects (age range 9 - 69 years) containing details of their age, sex and residential address. $5 \mathrm{ml}$ of blood was collected from each subject into EDTA 
treated tubes and centrifuged for 10 minutes. The plasma was separated and stored at $-20^{\circ} \mathrm{C}$ until analysed. Subjects had been previously confirmed HBsAg positive prior to assessing the HBV viral load test.

Study design: This is a descriptive retrospective study.

Sample population: This consists of five hundred and ninety four subjects, from all over Nigeria requesting HBV viral load test within 20 months. The inclusion criteria were those that tested positive for HBsAg. Only the first test carried out by a patient was included in this study.

Sample Analyses: This was carried out at the Human Virology unit of the Nigerian Institute of Medical Research, Lagos, Nigeria.

HBV DNA viral load assay: Samples were assayed for the quantity of hepatitis B virus according to the COBAS Amplicor HBV monitor test (Roche diagnostics $\mathrm{GmbH}$, Mannheim, Germany) manual, Version 2.0, a PCR based technique, at the Human Virology Unit, Nigerian Institute of Medical Research, Lagos, Nigeria. The HBV viral load results were expressed in DNA copies/ml, after converting from the $\mathrm{IU} / \mathrm{ml}$ value reported by the automated analyzer.

Statistical Analyses: This was done using Epi info version 2002 and test of significance using Kruskal-Wallis statistical packages. Differences of $p<0.05$ were taken to be statistically significant at 95\% confidence interval.

\section{RESULTS}

The age and sex distribution of the HBV viral load values are shown in table 1 . It revealed a hepatitis B DNA range of 4,145-68,011,800 DNA copies/ml. Male to female ratio was 2.9:1 respectively. The median $\mathrm{HBV}$ viral load for males and females were 10,941 and 10,257 DNA copies/ $\mathrm{ml}$ respectively ( $\mathrm{P}>0.005)$. The age bracket with the highest HBV prevalence was the 30-39 age group.

The steady increase in patient turn-out during the 20 month time period (ranging from 3-69 patients/month) is shown in figure 1 .

Geographical distribution of subjects assayed shows the largest group coming from the southwest of the country, $51.3 \%$, followed by the south-east $12.2 \%$, north-central and south-south with $10.3 \%$ and $8.8 \%$ respectively, as shown in table 2 .

The test-turnaround-times (TAT) from first assay until December 2009 are shown in figure 2. Initial TAT was 55 days (requiring the lab to call patients for result pick-up), but it gradually improved to 10 days as sample size increased. Of the 594 subjects tested, 2 results were sent by email in 2008 and 36 in 2009. Number of unclaimed results was 3 in 2008 and 10 in 2009. Number of repeat testing was 11 in 2008 and 12 in 2009.

TABLE 1

AGE AND SEX DISTRIBUTION OF OF PATIENTS AND THEIR HBV VIRAL LOAD VALUES (DNA COPIES/ML)

\begin{tabular}{|c|c|c|c|}
\hline $\begin{array}{c}\text { Age } \\
\text { group } \\
\text { (years } \\
\text { ) }\end{array}$ & $\mathrm{N} \quad(\%)$ & $\begin{array}{c}\text { Median } \\
\text { HBVL (DNA } \\
\text { copies/mL) }\end{array}$ & $\begin{array}{c}\mathbf{P} \\
\text { value }\end{array}$ \\
\hline $0-9$ & $1 \quad(0.23)$ & $68,011,800.0$ & \multirow[t]{7}{*}{0.0536} \\
\hline $10-19$ & $19 \quad(3.21)$ & $4,145.0$ & \\
\hline $20-29$ & $126(24.28)$ & $18,463.0$ & \\
\hline $30-39$ & $223 \quad(36.04)$ & $8,100.0$ & \\
\hline $40-49$ & 152 (24.11) & $8,363.0$ & \\
\hline $50-59$ & $\begin{array}{ll}53 & (9.55)\end{array}$ & $17,331.5$ & \\
\hline $60-69$ & $10 \quad(1.91)$ & $46,998.0$ & \\
\hline \multicolumn{4}{|l|}{ Sex } \\
\hline Male & 441 (74.2) & $10,941.0$ & \multirow[t]{3}{*}{0.3636} \\
\hline $\begin{array}{c}\text { Femal } \\
\text { e }\end{array}$ & $153(25.8)$ & $10,257.0$ & \\
\hline Total & $594(100)$ & $10,625.0$ & \\
\hline
\end{tabular}

TABLE 2

ZONAL DISTRIBUTION OF SUBJECTS ASSAYED FOR HEPATITIS B VIRAL LOAD IN NIGERIA

\begin{tabular}{|c|c|}
\hline $\begin{array}{c}\text { Geographical } \\
\text { Zones }\end{array}$ & $\begin{array}{c}\text { HBV viral load tests } \\
\text { N (\%) }\end{array}$ \\
\hline NE & $1(0.2 \%)$ \\
\hline NW & $3(0.5 \%)$ \\
\hline NC & $61(10.3 \%)$ \\
\hline SS & $52(8.8 \%)$ \\
\hline SE & $72(12.2 \%)$ \\
\hline SW & $305(51.3 \%)$ \\
\hline Unknown & $100(16.9 \%)$ \\
\hline Total & $594(100 \%)$ \\
\hline
\end{tabular}

\section{DISCUSSION}

Infection with HBV is under control in developed countries [1], but it is still a serious public health problem in developing countries like Nigeria. In this study we examined the viral load pattern of those assessing laboratory services at our site, being the only laboratory at present where HBV 
viral load is carried out commercially within the country. As such samples were received from a wide range of localities across the country (Table 2). There was a wide age range observed by the patients, with the highest prevalence being between 30-39 years. This compares to what was observed by Jatau and colleagues [13], and Belo [10].
In this study also, more males requested the test than the female counterparts. This is in consonance with those observed in previous studies [4]. This pattern could be because of the higher purchasing power of men, as the test is expensive. There was a wide disparity in the viral titre amongst the age groups, but it was of no statistical significance $(\mathrm{p}>0.0536)$.

FIGURE 1

PROFILE OF HBV VIRAL LOAD ASSAYS CARRIED OUT FROM MAY 2008 TO DECEMBER 2009

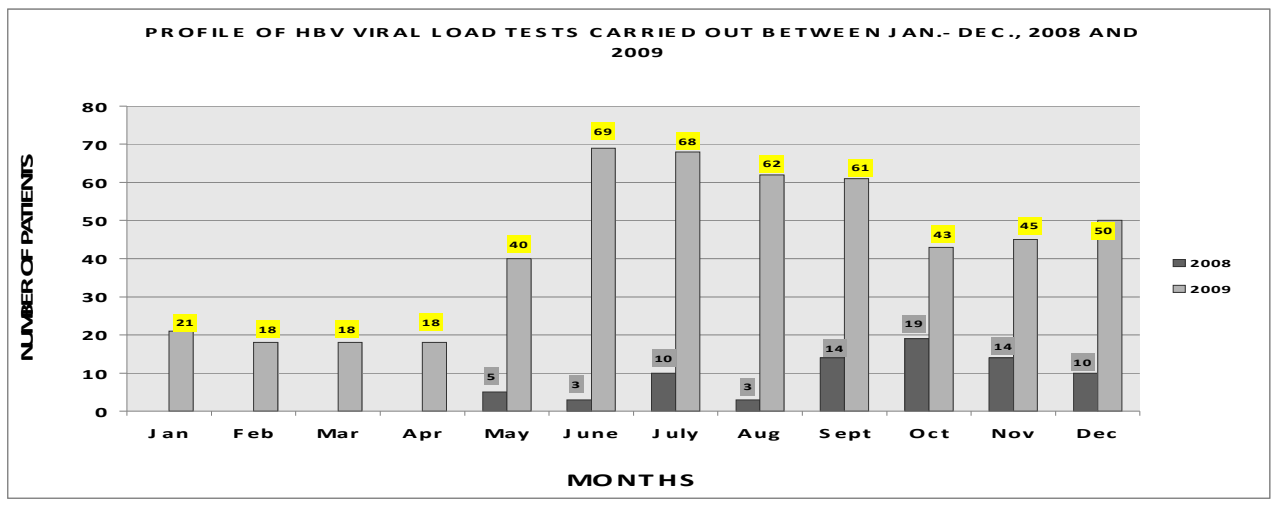

FIGURE 2

TEST-TURN-AROUND-TIME (TAT) PROFILE OF THE HBV VIRAL LOAD ASSAY

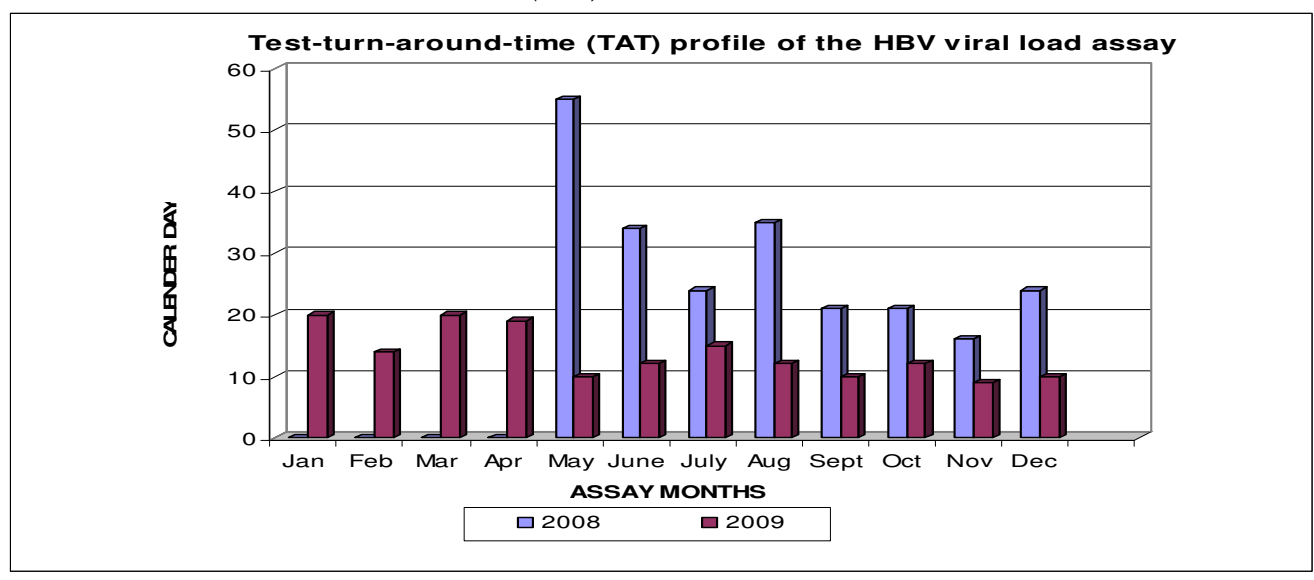

${ }^{*}$ TAT is the average number of calendar days from sample collection to lab assay

Since HBV viral load is an independent predictor of liver cancer risk, this points to the importance of both close clinical monitoring and antiviral treatment for individuals with high $\mathrm{HBV}$ viral load (>10, 000 copies $/ \mathrm{ml}$ ). The lower and upper limit of detection of the COBAS Hepatitis B monitor assay used was 316 and 199,880 DNA copies/ml respectively. HBV viral load may be seen as a good surrogate marker for slower clinical progression. The risk of HCC is closely associated with HBV, according to a Taiwanese study [17]. This association was shown to be independent of other risk factors, and to have a dose-response relationship. That study also showed that HBV DNA levels were persistently elevated in patients at highest risk of liver cancer [12]. There is therefore a high a risk of hepatocellular carcinoma among this population studied because of the high viral load observed. However this could be averted if regular/routine screening of the populace is in place. This risk could be minimized if the National programme on immunization (NPI) scheme for HBV vaccination is implemented. This study, again confirms the previously reported high prevalence of HBsAg in this part of the world [5]. Patients 
infected with HBV, treated with peginterferon2alfa and lamivudine are more likely to The challenges of carrying out the assay in our laboratory include, clients travelling from far to Lagos, limited shelf life of the reagents in the kits, delay in kit supply from Germany, electronic payment of the test by some clients amongst others. It is therefore suggested that there be put in place a national programme to mitigate the scourge of the virus which is a hundred times more infectious than HIV. Taiwan and Saudi Arabia have seen the tremendous impact of a mass programme of $\mathrm{HBV}$ immunization and the integration of $\mathrm{HBV}$ vaccine in the Expanded Programme of Immunization (EPI) in controlling HBV infectivity in their general population [17]. This is a route which Nigeria might well consider.

\section{REFERENCES}

1. Marjolis, H.S., Alter, M.J. and Hadler, S.C. (1991). Hepatitis B: Evolving epidemiology and implications for control. Sem. Liver Dis. 1991; 11: 84-92.

2. Szmuness, W., Dienstag, J.L, Purcell, R.H., Steven, C.E., Wong, D.C. and Ikram, H. (1977). The prevalence of antibody to hepatitis $B$ antigen in

5. (1983). Prevalence of Hepatitis B Infection Marker in two different geographical areas of Nigeria. Preceedings of the first international conference, 12-15 December, 1983, Lagos, Nigeria.

6. Akani, C.I., Ojule, A.C., Opurum, H.C. and Ejilemele, A.A. (2005). Seroprevalence of $\mathrm{HBs} \mathrm{Ag}$ in pregnant women in Port Harcourt,

8. Luka, S.A., Ibrahim, M.B. and Iliya, S.N. (2008). Seroprevalence of Hepatitis B surface antigen among pregnant women attending Ahmadu Bello University Teaching Hospital Zaria, Nigerian Journal of Parasitology 29 (1):38-41.

9. Forbi, J.C., Onyemauwa, N., Gyar, S.D. Oyeleye, A.O., Entonu P. and Agwale S.M. (2008) High Prevalence of Hepatitis B Virus among Female Sex Workers in have a sustained virologic response [19].

\section{CONCLUSION}

In conclusion, given the high viral load observed in this study group and the risk of HCC involved, it is recommended that there be health education for public and health care providers. Also screening and vaccination of all special risk groups especially surgeons, laboratory workers, dentists, emergency workers and law enforcement agents. A comprehensive effort is needed to promote hepatitis B testing in the Nigerian population, with community outreach, increased access to testing and physician education.

\section{AKNOWLEDGEMENTS}

We would like to acknowledge Roche Pharma Nigeria, for their effort at sensitizing clients and creating the awareness.

various parts of the world: a pilot study. Amer. J. Epidem. 1977; 106: 392-8.

3. Harry, T.O., Bajani, M.D., and Moses, A.E. (1994). Hepatitis B virus infection among blood donors and pregnant women in Maiduguri, Nigeria. East Africa Medical Journal 70: 596-597.

4. Nasidi, A.T.O., Vyazor, S.O., Numumbe, G.M.R. Azzan, B.B., and Ancinlev,

V.

A.

Nigeria. Post graduate Medical Journal 12(4): 266-270.

7. Agbede, O.O., Iseniyi, J.O., Kolewale, M.O. and Ojuowa, A. (2007). Risk Factors and seroprevalence of hepatitis $B$ antigenemia in mothers and their preschool children in Ilorin, Nigeria. Therapy, 4(1): 67-72.

Nigeria. Rev. Inst. Med. trop. S. Paulo 50(4):219-221.

10. Ejele, O., Nwauche C. and Erhabor O. (2004). The prevalence of hepatitis B surface antigen in HIVpositive patients in the Niger Delta Nigeria. Niger J Med 2004, 13: 1759.

11. Belo, A.C. (2000). Prevalence of hepatitis B virus markers in Surgeons in Lagos, Nigeria. East African Medical Journal Vol. 77 No. 5 May 2000; 283-285. 
12. Apurva A.M. and Jordan J.F. (2007). Viral hepatitis and HIV in Africa. AIDS Reviews 2007; 9: 25-39.

13. Aboulhab J. (2006). HBV viral load is an independent predictor of progression to hepatocellular carcinoma in chronic HBV patients. Euro Surveill. 2006; 11(1): E060126.6. Available online: http:// www.eurosurveillance.org

14. Jatau, E. D. and Yabaya, A. (2009). Sero Prevalence of Hepatitis B Virus In Pregnant Women Attending A Clinic In Zaria, Nigeria. Science World Journal Vol 4 (No 2) 2009, 7-9.

15. Yi-Cheng C., Chia-Ming C. and Yun-Fan L. (2010). Age-specific prognosis following spontaneous hepatitis $\mathrm{B}$ e antigen seroconversion in chronic hepatitis B. Hepatology, Vol 51, Issue 2, pages 435-444.

16. Orholm M., Aldershvile J., TageJensen U., Schlicting P., Nielson J.O., Hardt F., and Christoffersen P. (1981). Prevalence of hepatitis B virus infection among alcoholic patients with liver disease. J. Clin. Pathol. 1981; 34:1378-1380.

17. Chen C.J., Yang H.I., Su J., Jen C.L., You S.L., Lu S.N., Huang G.T. and Iloeje U.H. (2006). Risk of hepatocellular carcinoma across a biological gradient of serum hepatitis B virus DNA level. JAMA 2006; 295(1): 65-73.

18. Lin D.B., Wang H.M., Lee Y.L., Ling U.P., Changlai S.P., and Chen C.J. (1988). Immune status in preschool children born after mass hepatitis B vaccination program in Taiwan. Vaccine 1998; 16: 1683-7.

19. Lau G.K., Piratvisuth T. and Luo K.X. (2005). Peginterferon alfa2a, Lamivudine, and the combination for $\mathrm{HBeAg}$-positive chronic hepatitis B. N Engl J Med 2005; 352: 2682-95.

20. Al-Faleh F.Z., Al-Jeffri M., Ramia S., Al-Rashed R., Arif M., and Rezeig M. (1999). Seroepidemiology of hepatitis B virus infection in Saudi children 8 years after a mass hepatitis B vaccination programme. J Infect. 1999; 39: 167-70. 